\title{
EFEKTIVITAS MODEL CIRC DAN GGE TERHADAP KEMAMPUAN PEMECAHAN MASALAH MATEMATIKA SD
}

\author{
Nindya Intan Marviana ${ }^{1}$, Wahyudi ${ }^{2}$, Endang Indarini ${ }^{3}$ \\ ${ }^{1}$ Pendidikan Guru Sekolah Dasar, Universitas Kristen Satya Wacana, nindyaintanm13@gmail.com \\ ${ }^{2}$ Pendidikan Guru Sekolah Dasar, Universitas Kristen Satya Wacana, bimb.yudhi@gmail.com \\ ${ }^{3}$ Pendidikan Guru Sekolah Dasar, Universitas Kristen Satya Wacana, eindarini@gmail.com
}

\section{INFO ARTIKEL}

Riwayat Artikel:

Diterima: 14-04-2018

Disetujui: 21-04-2018

\section{Kata Kunci:}

CIRC

GGE

Kemampuan

Pemecahan Masalah

\begin{abstract}
ABSTRAK
Abstrak: Penelitian ini bertujuan untuk mengetahui efektifitas model CIRC dan GGE terhadap kemampuan pemecahana masalah matematika pada siswa kelas IV SD. Penelitian ini termasuk penelitian eksperimen semu. Uji prasyarat menunjukan kedua kelompok homogen dan berdistribusi normal. Uji T menggunakan uji $t$ Independent Sample Test menunjukan thitung $>\mathrm{t}$ tabel yaitu 4,137 > 2,0322 dan signifikan 0,000 < 0,05 yang berarti $\mathrm{H}_{0}$ ditolak dan $\mathrm{H}_{\mathrm{a}}$ diterima. Hal ini menunjukan adanya perbedaan efektivitas yang signifikan. Selanjutnya dilakukan uji normalitas gain yang menunjukan bahwa model CIRC lebih efektif disbanding model $G G E$ terhadap kemampuan pemecahan masalah matematika.

Abstract: This study aims to determine the effectiveness of CIRC and GGE models on the ability of math problem solvers in grade 4 elementary school students. This study included quasi-experimental research. The prerequisite test shows both homogeneous groups and normally distributed. T test using $t$ test Independent Sample Test shows $t$ count $>t$ table that is 4.137> 2.0322 and significant $0,000<0.05$ which means HO rejected and $\mathrm{Ha}$ accepted. This shows a significant difference in effectiveness. Furthermore, the gain normality test shows that the CIRC model is more effective than GGE model of mathematical problem solving ability.
\end{abstract}

\section{A. LATAR BELAKANG}

Permendikbud No 24 Tahun 2016 menyatakan pelaksanaan pembelajaran untuk Sekolah Dasar/Madrasah Ibtidaiyah (SD/MI) pada Kurikulum 2013 dilakukan dengan pendekatan tematik terpadu, terkecuali untuk pelajaran matematika dan PJOK sebagai mata pelajaran yang berdiri sendiri untuk kelas IV,V,VI. Pemisahan mata pelajaran matematika salah satunya disebabkan karena matematika memiliki karakteristik objek kajian yang berbeda dibanding mata pelajaran yang lain. Selain itu, pembahasan materi matematika yang terdapat dalam buku tematik K13 dirasa kurang mendalam. Karakteristik pembelajaran pada matematika erat kaitanya dengan kemampuan pemecahan masalah matematis. Siswa diharap mampu menguasai konsep-konsep dasar untuk dapat memecahkan permasalahan yang terdapat dalam soal matematika. Langkah pertama dalam memecahkan masalah matematis adalah dapat memahami masalah matematika itu sendiri (Fauziah: 2010). Kemampuan pemecahan masalah pada tahap perkembangan siswa masuk dalam tahap menganalisis dimana siswa dituntut untuk mampu menganalisis sebuah permasalahan serta mencari solusi dalam memecahkan masalah tersebut. Kemampuan menganalisis siswa masuk dalam kemampuan berpikir tingkat tinggi atau yang sering sidebut dengan Higher Order Thinking Skill (HOTS). Higher Order thinking conceived of as the top end of the Bloom's cognitive taxonomy: analyze, Evaluate, and Create, or un the older language, analysis, Synthesis, and Evaluation (Brookhart, 2010: 5).

Kemampuan siswa menyelesaikan suatu masalah dapat menjadi tolok ukur siswa dalam kemampuan memecahkan masalah sekaligus sebagai indikator keberhasilan siswa dalam belajar. Polya (dalam Suherman, 2003: 91) merumuskan adanya empat langkah dalam memecahkan masalah, yaitu understanding the problem (tahap siswa dalam memahami kondisi soal atau masalah dalam soal), devising a plan (tahap pemikiran sebuah rencana atau konsep), carrying out the plan (tahap pelaksanaan rencana) dan looking back (tahap siswa melakukan pengecekan ulang). Siswa yang sudah terbiasa mengerjakan soal dengan rumus praktis dalam menemukan hasil, mereka akan mengalami kesulitan dalam mengerjakan soal cerita yang membutuhkan langkah-langkah dalam pengerjaannya. Adanya rumusrumus praktis dapat melemahkan cara berpikir siswa yang sistematis. Hal ini dapat menyebabkan kemampuan siswa menjadi rendah sehingga mengalami kesulitan dalam mengerjakan soal dalam bentuk cerita, terlebih jika langkah dalam mengerjakan tidak sesuai dengan urutannya (Hanafi Maarif \& Wahyudi: 2015). 
Pengerjaan soal cerita harus sesuai dengan urutan/langkah-langkah karena akan mempermudah dalam memahami dan menyelesaikannya.

Mengatasi permasalahan tersebut maka diperlukan adanya usaha perbaikan pada pembelajaran matematika. Salah satunya yaitu dengan cara memperbaiki atau mengubah proses pembelajaran melalui penerapan model pembelajaran. Salah satu model yang temasuk pembelajaran kooperatif adalah model Cooperative Integrated Reading And Compotition (CIRC). Model $C I R C$ ini menyediakan pembelajaran yang mengarahkan siswa dalam memahami suatu bacaan. Dalam pelaksanaannya siswa terlibat secara aktif didalam kelompoknya. Setiap siswa dituntut saling bekerja sama dengan siswa lain dalam satu kelompok untuk menyelesaiakn persoalan yang diberikan oleh guru. Melalui penerapan CIRC, setiap anggota kelompok saling mengeluarkan ide-ide untuk memahami suatu konsep dan menyelesaikan sebuah permasalahan sehingga terbentuk pemahaman dan pengalaman belajar (Miftahul Huda, 2014: 221).

Cooperative Integrated Reading and Compotition (CIRC) sebagai sebuah program dalam mengajarkan siswa membaca, menulis dan seni berbahasa pada kelas yang lebih tinggi di sekolah Slavin (2005: 200). CIRC memiliki tiga prinsip dasar yaitu kemampuan membaca lisan, membaca pemahaman dan integrasi seni bahasa atau menulis. Langkah pembelajaran CIRC menurut Miftahul Huda (2014: 222) antara lain yaitu, pengenalan konsep, eksplorasi dan aplikasi, dan publikasi. Selanjutnya langkah pembelajaran CIRC di jabarkan kembali menjadi beberapa langkah yaitu, orientasi, pengenalan konsep, organisasi, eksplorasi dan aplikasi, serta publikasi.

Selain model pembelajaran CIRC, guru juga dapat menerapkan model pembelajaran Group to Group Exchange (GGE). Model pembelajaran GGE merupakan gabungan dari metode diskusi,, tanya jawab dan mengajarkan teman sebaya. Penerapan dari model pembelajaran ini bertujuan membiasakan siswa dalam bekerja sama, bermusyawarah, bertanggung jawab, menghormati pandangan atau tanggapan siswa lain, menumbuhkan sikap ketergantungan positif dan memberikan kesempatan pada siswa dalam mengembangkan potensinya (Silviana: 2010). Melalui penerapan model Group to Group Exchange, diharapkan kemampaun siswa dalam bekerja sama, berpendapat dan menyelesaikan permasalahan menjadi lebih baik serta mampu majikan dan mempresentasika apa yang telah mereka kerjakan.

Langkah pembelajaran model GGE yang pertama adalah pemilihan topik pembelajaran, dimana guru menjelaskan topik materi yang akan diperlajari. Selanjutnya siswa dibagi menjadi beberapa kelompok secara heterogen dan dengan bahan diskusi yang berbeda. Dalam kegiatan diskusi, setiap kelompok memiliki kebebasan dalam menyajikan hasil diskusi terkait permasalahan yang diberikan oleh guru. Langkah selanjutnya adalah presentasi, dimana setiap kelompok maju untuk memaparkan hasil diskusi mereka. Disinilah karakteristik model $G G E$ terlihat, yaitu proses pembelajaran dengan kegiatan saling mengajar antar kelompok. Selanjutnya setelah presentasi oleh perwakilan kelompok, guru mendorog siswa lain untuk bisa menanggapai presentasi sehingga terjadi proses tanya jawab antar kelompok (Murni: 2010).

Cooperative Integrated Reading And Compotition (CIRC) dan Group to Group Exchange (GGE) meskipun sama-sama termasuk model pembelajaran kooperatif, namun keduanya memiliki perbedaan dalam hal fokus pembelajaran. Model CIRC lebih menekankan siswa pada pemahaman suatu bacaan. Dalam penerapan CIRC setiap anggota kelompok saling menukarkan ide untuk memahami suatu konsep dalam menyelesaiakan suatu permasalahan sehingga akan terbentuk sebuah pemahaman. Karakteristik model CIRC yang lebih berfokus dalam pemahaman bacaan akan membantu siswa dalam menyelesaiakn permasalahan matematika yang biasanya berbentuk soal cerita.

Berbeda dengan model CIRC yang lebih menekankan dalam pemahaman bacaan. Model $G G E$ lebih menekankan siswa dalam kemampuan menyajikan dan menyampaikan hasil diskusi. Dalam penerapan model ini, siswa dibagi menjadi beberapa kelompok heterogen dan diberikan permasalahan berbeda antar kelompok. Pada akhir pembelajaran setiap kelompok bertugas untuk menjelaskan hasil diskusi kepada seluruh siswa. Sedangkan siswa lainnya memperhatikan dan memberikan tanggapan serta pertanyaan terkait hasil diskusi yang dipresentasikan. Melalui penerapan model GGE diharapkan dapat meningkatkan kemampuan penyelesaian masalah matematika, karena siswa akan mengetahui berbagai macam permasalahan matematika beserta penyelesaiannya.

Tulisan ini akan memberikan gambaran bagaimana CIRC dan GGE dilaksanakan dalam pembelajaran matematika serta memberikan gambaran tentang efektifitas kedua model terhadap kemampuan pemecahan masalah matematika siswa kelas IV SD pada materi keliling dan luas bangun datar persegi, persegi panjang, dan segitiga.

\section{B. METODE PENELITIAN}

\section{Jenis Penelitian}

Jenis penelitian ini adalah penelitian kuantitatif dengan metode penelitian eksperimen semu (quasi eksperimental research). Pemilihan metode disebabkan karena tidak semua variabel dan kondisi eksperimen dapat diatur serta dikontrol secara ketat. Desain penelitian yang digunakan adalah penelitian eksperimen kuasi dengan pola nonequivalent control group design. Adapun gambaran mengenai desain penelitian nonequivalent control group design menurut Johnson \& Christensen (2014). 


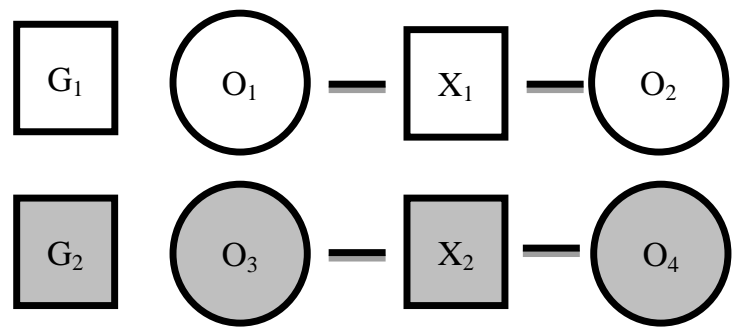

Gambar 1. Nonequivalent Control Group Design

Keterangan:

$\mathrm{G}_{1}$ : Kelompok Eksperimen Pertama

$\mathrm{G}_{2}$ : Kelompok Eksperimen Kedua

$\mathrm{O}_{1}$ : Hasil pretest kelompok eksperimen pertama

$\mathrm{O}_{2}$ : Hasil posttest kelompok eksperimen pertama

$\mathrm{X}_{1}$ : Model 1 dengan $C I R C$

$\mathrm{X}_{2}$ : Model 2 dengan $G G E$

$\mathrm{O}_{3}$ : Hasil pretest kelompok eksperimen kedua

$\mathrm{O}_{4}$ : Hasil posttestkelompok eksperimen kedua

Penelitian ini dilaksanakan di Gugus Pangeran Diponegoro, Kecamatan Tengaran, Kabupaten Semarang. Materi pembelajaran yang dipilih adalah penyelesaian masalah terkait keliling dan luas bangun datar persegi, persegi panjang, dan segitiga.

Langkah-langkah dalam penelitian ini adalah seagai berikut: memberikan pretest pada kedua kelompok eksperimen.. Pemberian pretest digunakan untuk mengetahui kemampuan awal siswa sebelum diberikan perlakuan. Kemudian untuk kelompok eksperimen I diberikan perlakuan dengan model CIRC dan kelompok eksperimen II dengan model Group to Group Exchange. Selanjutnya kedua kelas akan diberikan posttest setelah mendapat perlakuan. Soal posttest digunakan untuk mengetahui ada tidaknya pengaruh dari perlakuan antara model CIRC dan Group to Group Exchange.

\section{Teknik Pengumpulan Data}

Data penelitian dikumpulkan melalui tes dan nontes (observasi) untuk kedua kelompok eksperimen. Tes yang digunakan dalam penelitian ini adalah tes kemampuan pemecahan masalah berupa tes awal (pretes) dan tes akhir (posttes) yang berbentuk tes uraian. Sedangkan nontes (observasi) terdiri atas lembar observasi guru dan siswa yang digunakan untuk mengukur atau menilai hasil serta proses belajar seperti tingkah laku guru, kegiatan diskusi siswa serta digunakan untuk melihat kesesuaian penerapan langkah-langkah pembelajaran.

Adapun langkah yang digunakan untuk mengumpulkan data adalah sebagai berikut: menyusun kisi-kisi, menyusun intrumen penelitian,melakukan uji validitas dan reliabilitas menggunakan SPSS 20.0 for windows, memberikan pretest, melakukan tindakan penelitian, memberikan tindakan penelitian, memberikan posttest, dan yang terakhir adalah menganalisis data.

\section{Teknik Analisis Data}

Analisis data dilakukan dengan menggunakan analisis diskriptif, uji normalitas, dan uji homogentitas sebagai uji prasyarat sebelum dilakukan uji beda ratarata dan uji hipotesis. Analisis deskriptif dilakukan untuk mendeskripsikan keadaan sebelum dan sesudah diberikan perlakuan pada kedua kelompok eksperimen terhadap kemampuan pemecahan masalah dengan materi keliling dan luas bangun datar. Selanjutnya uji normalitas digunakan untuk melihat penyebaran data pada kelompok eksperimen I dan kelompok eksperimen II berdistribusi normal atau tidak. Uji normalitas pada penelitian ini menggunakan teknik Shapiro-Wilk dengan SPSS 20.0 for windows. Sedangkan uji homogenitas digunakan untuk mengetahui apakah sampel eksperimen I dan kelas eksperimen III sebelum memiliki variasi yang sama.

Setelah melakukan uji prasyarat dengan uji normalitas dan homogenitas, selanjutnya dilakukan uji T dengan Independent Sample T-Test untuk menganalisis keefektivan model CIRC dan GGE terhadap kemampuan pemecahan masalah matematika. Data yang dianalisis merupakan data posttest. Selanjutnya dilakukan uji hipotesis dimana. kriteria keputusannya adalah $\mathrm{H}_{\mathrm{o}}$ ditolak jika $t_{\text {hitung }}>t_{\text {tabel, }}$ serta dengan nilai signifikansi diatas $5 \%(>0,05)$.

Setelah diketahui keefektifan model terhadap kemampuan pemecahan masalah, selanjutnya dilakukan analisis data untuk mengetahui model yang lebih efektif. Untuk memperkuat keefektifan pada kelompok eksperimen I dan II dilakukan analisis menggunakan uji normalitas gain

\section{HASIL DAN PEMBAHASAN}

\section{Hasil Penelitian}

Data yang diperoleh dalam penelitian ini adalah data posttest dan pretest kemampuan pemecahan masalah matematika. Adapun komparasi hasil pengukuran kemampuan pemecahan masalah tersaji dalam Tabel 1.

TABEL 1

KOMPARASI HASIL PENGUKURAN KEMAMPUAN PEMECAHAN MASALAH SISWA

\begin{tabular}{cccc}
\hline \multirow{2}{*}{ Pengukuran } & \multicolumn{2}{c}{ Rata-rata skor (mean) } & \multirow{2}{*}{ Selisih } \\
\cline { 2 - 3 } & Eksperimen I & Eksperimen II & \\
\hline Pretest & 70,89 & 66,42 & 4.472 \\
Posttest & 87,14 & 80.34 & 6,802 \\
\hline
\end{tabular}

Berdasarkan hasil komparasi rata-rata pada tabel 1, rata-rata skor pretest antara kelompok eksperimen I yang mendapat perlakuan CIRC dan kelompok eksperimen yang mendapat perlakuan $G G E$ terdapat perbedaan sebesar 4,472. Sedangkan untuk rata-rata skor posttest antara kelompok eksperimen I dan kelompok eksperimen II terdapat perbedaan sebesar 5,194. Adapun diagram komparasi data kelompok eksperimen I dan kelompok eksperimen II tersaji dalam Gambar 1. 


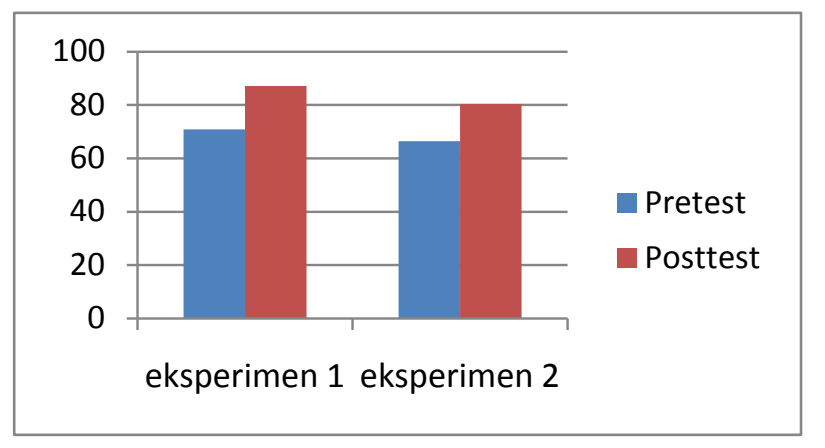

Gambar 2. Komparasi Data Kelompok Eksperimen

Berdasarkan Gambar 1 diketahui adanya peningkatan data pada kelompok eksperimen I yang mendapat perlakuan dengan CIRC maupun kelompok eksperimen II yang mendapat perlakuan dengan model GGE.

Data penelitian yang diperoleh selanjutnya dilakukan uji prasyarat yaitu dengan melakukan uji normalitas dan uji homogenitas. Hasil uji normalitas tersaji pada tabel 2 sedangkan uji homogenitas tersaji pada tabel 3 dan 4 .

TABEL 2

UJI NORMALITAS KELOMPOK EKPERIMEN I DAN EKPERIMEN II

\begin{tabular}{|ll|r|r|r|}
\hline & & \multicolumn{3}{|c|}{ Shapiro-Wilk } \\
\cline { 3 - 5 } & Kelomnok & Statistic & \multicolumn{1}{c|}{ df } & \multicolumn{1}{c|}{ Sig. } \\
\hline Pretest & eksperimen 1 & .930 & 14 & .307 \\
& eksperimen 2 & .952 & 22 & .351 \\
Posttest & eksperimen 1 & .877 & 14 & .052 \\
& eksperimen 2 & .922 & 22 & .082 \\
\hline
\end{tabular}

Berdasarkan tabel 2 dapat diketahui hasil uji normalitas hasil belajar pretest dan posttest. Uji normalitas menggunakan teknik Shapiro-Wilk dengan SPSS 20.0 for windows jika nilai signifikansi > 0,05 maka data dikatakan berdistribusi normal dan sebaliknya jika nilai signifikansi $<0,05$ maka data tidak berdistribusi normal. Dari tabel 2 diketahui keempat nilai baik nilai pretest maupun posttest memiliki nilai signifikansi > 0,05. Sehingga dapat disimpulkan bahwa data berdistribusi normal.

TABEL 3

UJI HOMOGENITAS SEBELUM PERLAKUAN

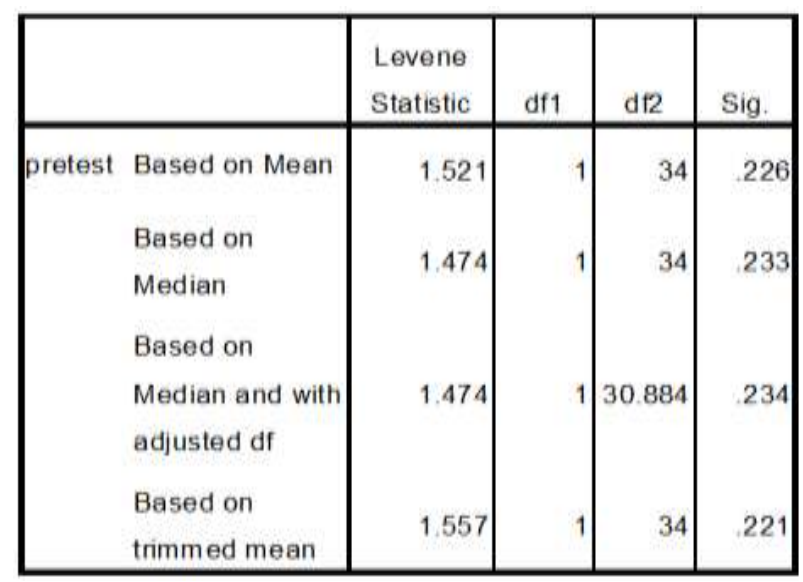

TABEL 4

UJI HOMOGENITAS SETELAH PERLAKUAN

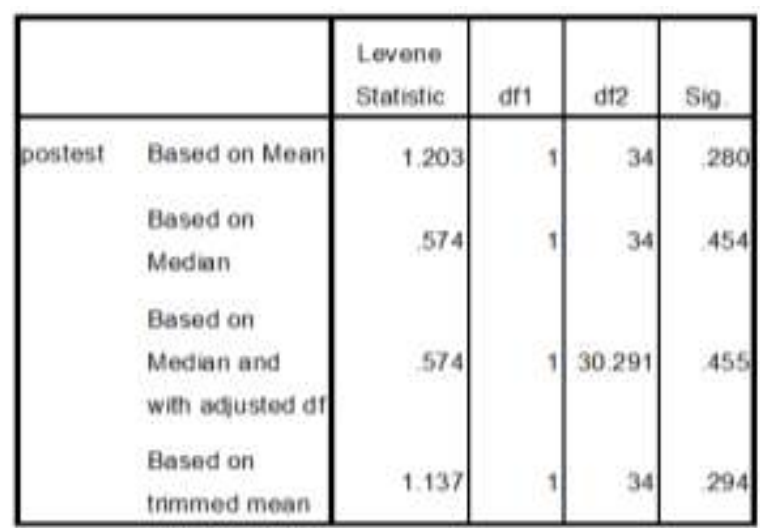

Tabel 3 dan 4 menunjukan hasil uji homogenitas menggungakan metode Lavene's Test. Interpretasi dilakukan dengan memilih salah satu statistic, yaitu statistik yang didasarkan pada rata-rata (based on mean). Pada tabel 3 diketahui uji homogenitas sebelum perlakuan memiliki nilai signifikansi sebesar 0,167 dimana > 0,05 yang berarti kedua kelas sebelum perlakuan memiliki varian yang sama atau homogen. Selanjutnya pada tabel 4 menunjukan uji homogenitas setelah perlakuan memiliki nilai signifikansi sebesar 0,546 dimana > 0,05 yang berarti kedua kelas setelah perlakuan memiliki varian yang sama atau homogen.

\section{Uji Beda Rata-rata}

Berdasarkan uji prasyarat yang telah dilakukan, diketahui bahwa data berdistribusi normal dan homogen. Selanjutnya dilakukan analisis uji $\mathrm{T}$ menggunakan independent sample test dengan bantuan SPSS 20.0 for windows untuk mengetahui ada tidaknya perbedaan efektifitas antara kedua kelompok eksperimen terhadap kemampuan pemecahan masalah matematika. Hasil analis menggunakan uji $\mathrm{T}$ disajikan pada tabel 5 .

TABEL 5

UJI T DENGAN INDEPENDENT SAMPLE T-TEST

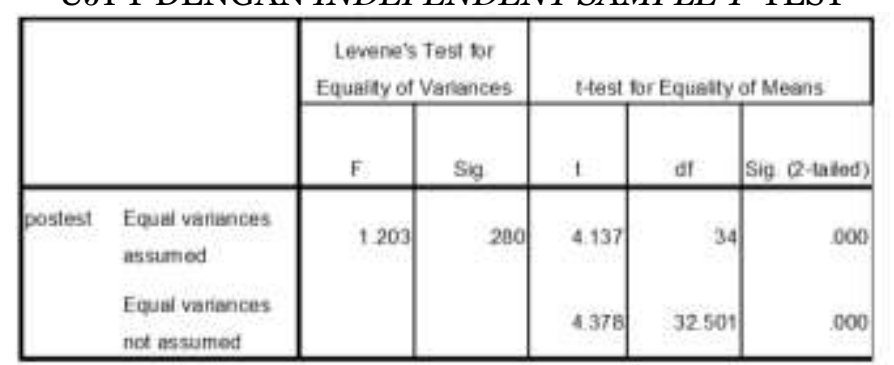

Hasil uji t pada tabel 5 menunjukan $t_{h i t u n g}$ sebesar 4,137 dengan signifikansi pada kolom Sig.(2-tailed) sebesar 0,00o. Berdasarkan analisis data diketahui $\mathrm{t}_{\text {tabel }}$ diperoleh sebesar 2,0322. Sedangkan untuk mengetahui $\mathrm{t}_{\text {tabel }}$ dengan bantuan MS.Excel yaitu dengan menulis rumus $\quad\{=\mathrm{TINV}$ (probability:deg_freedom) $\}$ dengan probability merupakan tingkat signifikan yang dipakai yaitu 5\% (0,05), sedangkan deg_freedom merupakan $\mathrm{df}$ berdasarkan hasil uji t yaitu sebesar 34 . 


\section{Uji Hipotesis}

Berdasarkan pada analisis uji Independent Sample $T$-Test pada tabel 34 kemudian dilakukan uji hipotesis penelitian. Pengujian hipotesis merupakan langkah utuk menentukan apakah hipotesis diterima atupun ditolak. Hipotesis yang diajukan dalam penelitian ini adalah.

$\mathrm{H}_{\mathrm{o}} \quad$ : Tidak ada perbedaan efektifitas yang signifikan dalam penerapan model pembelajaran CIRC dan $G G E$ pada siswa kelas 4 SD.

$\mathrm{H}_{\mathrm{a}}$ : Ada perbedaan efektifitas yang signifikan dalam penerapan model pembelajaran CIRC dan $G G E$ pada siswa kelas 4 SD.

Untuk menguji hipotesis maka digunakan hasil output olahan SPSS 20.0 for windows.

Kriteria Pengujian:

a. Menggunakan koefisien Sig. dengan ketentuan

1) Jika nilai sig. < 0,05 maka tolak $\mathrm{H}_{0}$

2) Jika nilai sig. > 0,05 maka terima $\mathrm{H}_{0}$

b. Menggunakan koefisien $t$ hitung denganketentuan

1) Jika koefisien $t$ hitung $>t$ tabel maka tolak $\mathrm{H}_{\mathrm{o}}$

2) Jika koefisien $t$ hitung $<\mathrm{t}$ tabel maka terima $\mathrm{H}_{\mathrm{o}}$

Hasil perhitungan uji hipotesis menggunakan uji $t$ Independent Sample Test. Berdasarkan tabel 5 menunjukan skor koefisien t sebesar 0,933 dengan nilia signifikan sebesar o,ooo yang berarti lebih kecil dari $0,05(0,000<0,05)$. Dari uji t menunjukan $t$ hitung $>t$ tabel yaitu 4,137>2,0322 dan signifikan $0,000<0,05$ yang menunjukan bahwa $\mathrm{H}_{\mathrm{o}}$ ditolak dan $\mathrm{H}_{\mathrm{a}}$ diterima. $\mathrm{Hal}$ ini menunjukan bahwa Ada perbedaan pengaruh yang signifikan dalam penerapan model pembelajaran Cooperative Integrated Reading And Compotition (CIRC) dan Group to Group Exchange terhadap kemampuan pemecahan masalah matematika pada siswa kelas 4 SD.

Selanjutnya berdasarkan hasil uji beda rata-rata posttest terlihat bahwa nilai kemampuan pemecahan masalah matematike pada kelompok eksperimen I lebih tinggi dibandingkan kelompok eksperimen II. Hal ini menunjukan bahwa perlakuan yang dilakukan pada kelompok eksperimen I lebih efektif dibandingkan kelompok eksperimen II. Untuk memperkuat keefektifan pada kelompok eksperimen, maka dapat dianalisis menggunakan uji normalitas gain. Untuk menghitung Ngain antara pretest dan posttest dapat menggunakan rumus Hake (Meltzer,2002;Archambault,2008). Sedangkan kategori perolehan skor N-gain dapat dilihat pada tabel 6.

$$
N-\text { gain }=\frac{S \text { posttest }-S \text { pretest }}{S \text { max }-S \text { pretest }}
$$

Keterangan: S posttest: Skor posttest S pretest : Skor pretest $\mathrm{S} \max$ : Skor maksimum ideal
TABEL 6

KATEGORI PERILEHAN SKOR N-GAIN

\begin{tabular}{cc}
\hline Batasan & Kategori \\
\hline $\mathbf{g}>\mathbf{0 , 0 7}$ & Tinggi \\
$\mathbf{0 , 3}<\mathbf{g} \leq \mathbf{0 , 0 7}$ & Sedang \\
$\mathbf{g} \geq \mathbf{0 , 3}$ & Rendah \\
\hline
\end{tabular}

Hasil uji normalitas gain kelas eksperimen I menunjukan bahwa rata-rata kelas eksperimen I mengalami peningkatan sebesar 0,56 yang berarti $\mathrm{N}$ gain rata-rata kelas eksperimen I termasuk peningkatan kategori sedang. Sedangkan peningkatan di kelas eksperimen II sebesar 0,41. Pada kelas eksperimen I secara keseluruhan siswa memiliki peningkatan nilai kemampuan pemecahan masalah dalam kategori sedang dan hanya 1 orang yang memiliki peningkatan dalam kategori rendah. Sehingga secara keseluruhan dapat disimpulkan bahwa model CIRC lebih efektif terhadap kemampuan pemecahan masalah matematika pada siswa kelas IV SD

\section{SIMPULAN DAN SARAN}

Dalam penelitian ini dapat disimpulkan bahwa terdapat perbedaan efektifitas yang signifikan dalam penerapan model pembelajaran CIRC dan Group to Group Exchange terhadap kemampuan pemecahan masalah matematika siswa kelas IV SD. Hal ini di tunjukkan berdasarkan hasil uji prasyarat yang telah dilakukan yaitu uji normalitas dan homogenitas menunjukan signifikansi atau probabilitas normal dan homogen, selanjutnya dilakukan uji t menggunakan uji $t$ Independent Sample Test. diketahui skor koefisien $\mathrm{t}$ sebesar 0,4,137 dengan nilia signifikan sebesar 0,000 yang berarti lebih kecil dari 0,05 $(0,000<0,05)$. Dari uji $\mathrm{t}$ menunjukan thitung $>\mathrm{t}$ tabel yaitu 4,137 $>2,0322$ dan signifikan $0,000<0,05$ yang menunjukan bahwa $\mathrm{H}_{\mathrm{o}}$ ditolak dan $\mathrm{H}_{\mathrm{a}}$ diterima. Hal ini menunjukan adanya perbedaan pengaruh yang signifikan dalam penerapan model pembelajaran Cooperative Integrated Reading And Compotition (CIRC) dan Group to Group Exchange terhadap kemampuan pemecahan masalah matematika pada siswa kelas 4 SD. Selanjutnya dilakukan uji normalitas gain untuk melihat keefektivan model terhadap kemampuan pemecahan masalah yang menunjukan peningkatan pada kelas eksperimen I sebesar 0,56 dan pada kelas eksperimen II sebesar 0,41. Sehingga dapat disimpulkan bahwa perlakuan di kelas eksperimen I menggunakan model CIRC lebih efektif terhadap kemampuan pemecahan masalah matematika pada siswa kelas IV SD

Saran yang dapat diajukan untuk keterlaksanaan proses pembelajaran didalam kelas sesuai dengan Kurikulum 2013 adalah dapat diterapkannya model CIRC dan GGE sebagai salah satu alternatif dalam meningkatkan kemampuan pemecahan masalah matematika siswa SD. Namun dalam penerapan perlu diperhatikan karakteristik dan kondisi siswa serta sekolah. 


\section{UCAPAN TERIMA KASIH}

Ucapan terima kasih yang sebesar-besarnya diberikan kepada Bapak Wahyudi, S.Pd., M.Pd selaku pembimbing 1 dan Ibu Dra. Endang Indarini, M.Pd Selaku pembimbing 2 yang senantiasa memberi bimbingan, nasehat, dan motivasi kepada penulis dengan penuh kesabaran sehingga penelitian ini dapat selesai dengan baik. Terima kasih juga kepada kedua orang tua yang senantisa memberikan dukungan dan doa. Tidak lupa kepada teman-teman yang tidak dapat penulis sebutkan satu-persatu yang sudah memberikan dukungan dan semangat sehingga penulis dapat menyelesaikan penelitian ini dengan baik.

\section{DAFTAR RUJUKAN}

[1] Brookhart, S. M. (2010). How To Assess Higher Order Thingking Skills In Your Classroom. Alexandria: ASCD.

[2] Fauziah, A. (2010). Peningkatan Kemampuan Pemahaman Pemecahan Masalah Matematika Siswa SMP Melalui Strategi REACT. Forum Kependidikan, 30(1).

[3] Huda, M. (2014). Model-Model Pengajaran dan Pembelajaran. Yogyakarta: Pustaka Pelajar.

[4] Maarif, H. \&. (2015). Eksperimentasi Problem Based Learning Dan Circ Dalam Menyelesaikan Soal Cerita Matematika Siswa Kelas 5 Sd. Scholaria: Jurnal Pendidikan dan Kebudayaan, 5(2), 97-115.

[5] Murni, A. N. (2010). Penerapan Metode Belajar Aktif Tipe Group To Group Exchange (GGE) Untuk Meningkatkan Hasil Belajar Matematika Siswa Kelas X IPS 1 MAN 2 Model Pekanbaru . Jurnal Penelitian Pendidikan, Vol, 11(2), 1-1.

[6] Permendikbud No 24 Tahun 2016 Tentang pelaksanaan pembelajaran pada Sekolah Dasar/Madrasah Ibtidaiyah $(S D / M I)$.

[7] Polya, G. (1973). How To Solve It. New Jersey: Princeton University Press.

[8] Silviana, P. d. (2010). Upaya Meningkatkan Prestasi Belajar Matematika Siswa dengan Pembelajaran Aktif Menggunakan Strategi Group to Group Exchange Melalui Bantuan Tutor sebaya di Kelas X SMA Muhammadiyah 5 Karanggeneng Lamongan. Jurnal Semnas. Pendidikan Matematika dan Statistika UNIPA Surabaya.

[9] Slavin, R. E. (2010). Cooperative Learning Teori. Bandung: Nusa Media.

\section{Biografi Penulis Utama}

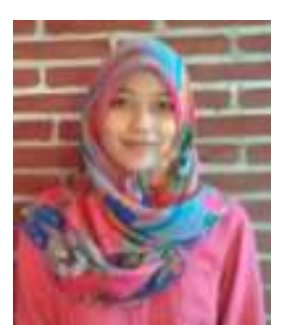

Penulis bernama lengkap Nindya Intan Marviana lahir pada tanggal 25 Maret 1996 di Salatiga. Putri pertama dari suami istri yang bernama Mahmud dan Trianita Jumtini dan memiliki 1 saudara laki-laki. Penulis telah mengenyam pendidikan selama 16 tahun. Pendidikan Sekolah Dasar di SD Kauman Kidul Salatiga. Pendidikan sekolah menengah di SMP Negeri 02 Salatiga. Pendidikan menengah atas di SMA Negeri 3 Salatiga. Pada saat ini penulis melanjutkan studi di Universitas Kristen Satya Wacana sejak tahun 2014. 